\title{
KRITIK KONSEPTUALISASI \\ PEMEGANG HAK DAN PEMEGANG KEWAJIBAN DALAM \\ UNDANG-UNDANG HAK ASASI MANUSIA
}

\author{
Muktiono \\ Fakultas Hukum Universitas Brawijaya \\ Jl. MT. Haryono No. 169 Malang \\ Email: muktiono_fh@yahoo.com
}

\begin{abstract}
:
The Act No.39 of 1999 on Human Rights has strategic position due to its position as reference law for every lower legislation in the area of human rights, and therefore to some extent will influence the State complience in promoting human rights. One of the most central issues in the Act No. 39 of 1999 on Human Rights is about the conceptualization of human rights 'elements that are 'rights holder' and 'duties-bearer'. There has been contradiction in terminological use of 'rights holder' and 'duties-bearer' by both state apparatus and community members. This research will conduct criticism to the conceptualization of 'rights holder' and 'dutiesbearer' in the Human Rights Act by means of interpretative study based on the relation between law and language. The output of this study is intended to contribute in enriching conceptual reference for legal interpretation conducted by the judge in the court in relation to human rights case; giving theoretical framework for legislature and government in establishing laws and regulation, policy, program, and plan as efforts to respect, protect, fulfil, and promote human rights.
\end{abstract}

Key words: rights, duties, human rights

\begin{abstract}
Abstrak
Undang-undang Nomor 39 Tahun 1999 tentang Hak Asasi Manusia memiliki posisi strategis karena menjadi dasar dan rujukan dalam pembentukan peraturan perundang-undangan di bawahnya dan oleh karena itu akan menentukan kualitas kebijakan dan tindakan negara terkait penegakan Hak Asasi Manusia. Salah satu elemen esensial dalam penormaan definiendum HAM adalah "Pemegang Hak (rights holder)" dan "Pemegang Kewajiban (duties-bearer)". Penelitian ini dilakukan dengan menggunakan metode normatif konseptual yang ditujukan untuk melakukan pengujian secara kritis terhadap konstruksi norma "Pemegang Hak (rights holder)" dan "Pemegang Kewajiban (duties-bearer)" yang ada dalam Undang-Undang Nomor 39 Tahun 1999 tentang Hak Asasi Manusia. Latar belakang faktual diselenggarakannya penelitian ini adalah karena terjadinya kontradiksi penggunaan terminologi "Pemegang Hak (rights holder)" dan "Pemegang Kewajiban (duties-bearer)" di ruang-ruang publik antara lain oleh otoritas negara, aktivis Hak Asasi Manusia, dan masyarakat. Kontribusi dari luaran penelitian (output) adalah pengayaan basis atau acuan interpretasi dalam ratio decidendi maupun obiter dictum para hakim terkait penanganan perkara pelanggaran (violation) maupun penyalahgunaan (abuse) Hak Asasi Manusia; selain itu, memberikan asistensi kepada otoritas legislatif dan eksekutif dalam menyusun kebijakan, program, rencana, dan tindakan terkait Hak Asasi Manusia sehingga mempunyai tingkat fisibilitas tinggi karena kejelasan pada aspek pelaksana kewajiban oleh lembaga-lembaga negara serta penargetan yang lebih jelas terkait siapa yang menerima manfaatnya.
\end{abstract}

Kata kunci: hak, kewajiban, HAM 


\section{Latar Belakang}

Pasca terungkapnya pelaku penembakan terhadap empat tahanan di Lembaga Pemasyarakat Cebongan, Yogyakarta, oleh sekelompok oknum anggota pasukan elit Komando Pasukan Khusus (Kopassus), ruang publik kemudian diramaikan oleh pendapat yang pro dan kontra terkait ada atau tidaknya pelanggaran Hak Asasi Manusia (selanjutnya disebut HAM) dalam kasus tersebut. Menteri Pertahanan, Purnomo Yusgiantoro, menyatakan bahwa tidak terjadi pelanggaran HAM dengan alasan karena kasus tersebut bukan merupakan kebijakan sistematis oleh pimpinan lembaga melainkan inisiatif dari para oknum pelaku sehingga tidak perlu dibentuk dewan kehormatan militer melainkan peradilan militer biasa $^{1}$. Sikap berbeda diberikan oleh Komisi Nasional HAM (Komnas HAM) yang menyatakan bahwa dalam kasus Cebongan tersebut berdasarkan beberapa indikator dari hasil investigasinya menunjukkan telah terjadinya pelanggaran hak untuk hidup, hak mendapatkan keadilan, dan hak untuk tidak mendapat perlakuan kejam, tidak manusiawi dan merendahkan martabat manusia ${ }^{2}$.

Contoh di atas menunjukan bahwa meskipun pada kasus yang sama dan menggunakan dasar acuan undang-undang yang juga sama, tetapi pada lembaga negara yang berbeda memiliki pandangan yang berbeda pula. Kepentingan dan sudut pandang kelembagaan yang berbeda tentu menjadi titik awal perbedaan tersebut dimana Menteri Pertahanan mempunyai kepentingan untuk menjaga harmoni hubungan kerja dengan jajaran TNI sedangkan Komnas HAM berada pada posisi yang moderat di antara korban dan pelaku. Situasi tersebut tentu dapat dimaklumi dalam konteks masing-masing pihak mempunyai orientasi kepentingan dan karakter kelembagaan yang berbeda; tetapi menjadi problematik ketika pandangan yang berbeda tersebut bersumber pada kerancuan aturan hukum yang seharusnya mempunyai karakter kepastian dalam implementasinya serta tidak multi-interpretasi. Hukum merupakan norma umum yang berlaku secara setara bagi setiap orang sesuai dengan prinsip kesetaraan di depan hukum (equality before the law). Tanpa kepastian, hukum tidak lagi layak untuk disebut sebagai hukum karena telah kehilangan karakter perlindungannya dan rentan terhadap penyalahgunaan oleh kekuasaan.

Pada kasus yang berbeda, Susilo Bambang Yudhoyono, Presiden Republik Indonesia, menyatakan bahwa peran dominan dalam menjaga kerukunan antar umat beragama

1 BBC Indonesia, Kasus Cebongan, tidak Melanggar HAM, http://www.bbc.co.uk/indonesia/berita_ indonesia/2013/04/130411_menhan_kasus_cebongan.shtml, diakses 25 Maret 2014 pukul 10.00 WIB.

2 Hukum Online, Komnas HAM Temukan Pelanggaran HAM Kasus Cebongan, http://www.hukumonline. com/berita/baca/lt51c18e3b23ff9/komnas-ham-temukan-pelanggaran-ham-kasus-cebongan, diakses 25 Maret 2014 pukul 12.30 WIB. 
adalah berada di tangan Majelis Ulama Indonesia $(\mathrm{MUI})^{3}$. MUI sebagai lembaga non-negara dan menjadi perwakilan satu kelompok agama saja, yaitu Islam, tentu memiliki banyak keterbatasan untuk mengambil alih fungsi-fungsi negara yang karakter utamanya adalah bersifat netral. Selain itu, MUI juga mempunyai keterbatasan dalam hal sumber daya organisasi, keuangan dan kewenangan. Dalam perspektif hak atas perlindungan terhadap kebebasan beragama dan berkeyakinan, tentu pernyataan presiden tersebut menyiratkan adanya pembagian beban kewajiban negara, yaitu perlindungan hak, kepada lembaga non-negara.

Dua kasus di atas dapat menjadi titik awal untuk mempermasalahkan tentang bagaimana sebenarnya hukum HAM di Indonesia mengatur tentang eksistensi pemangku kewajiban (duties-bearer) dan pemegang hak (rights holder) serta bagaimana relasi di antara keduanya. Secara normatif, secara tegas Pasal 28I ayat (4) Undang-Undang Dasar Negara Republik Indonesia Tahun 1945 menyatakan bahwa negara, dan terutama Pemerintah, adalah pihak yang mempunyai beban kewajiban untuk menghormati, melindungi, dan memenuhi HAM. Ketentuan serupa juga diatur dalam Pasal 8 UndangUndang Nomor 39 Tahun 1999 tentang HAM (selanjutnya disebut UU HAM). Namun demikian, pengertian HAM dalam Pasal 1 dalam Undang-Undang tersebut menyatakan bahwa " HAM adalah seperangkat hak yang...wajib dihormati, dijunjung tinggi dan dilindungi oleh negara, hukum Pemerintah, dan setiap orang..." yang menyuratkan adanya pembagian beban (burden sharing) terkait aspek penghormatan, perlindungan, dan pemenuhan HAM.

Kontradiksi yang terjadi baik secara internal dalam konseptualisasi norma UU HAM, antara UU HAM dengan Konstitusi, maupun antara norma tersebut dengan praktik sosial oleh aparatur negara dan kegiatan masyarakat, telah menjadi fenomena terkait hukum dan HAM. Yang menjadi pertanyaan besar adalah terkait prospek tercapainya tujuan dari keberlakuan hukum yaitu kemanfaatan, kepastian, dan keadilan dimana satu aspek dengan aspek yang lain bersifat saling menguatkan ${ }^{4}$ baik secara yuridis, sosiologis maupun filosofis 5 .

Berdasarkan latar belakang di atas maka dapat dirumuskan suatu permasalahan sebagai berikut:

1. Bagaimanakah eksistensi dan interelasi pemegang hak (right holder) dan pemegang kewajiban (duty-bearer) dalam UU HAM?

2. Bagaimanakah konstruksi kritik atas perumusan pemegang hak (right holder)

3 Novy Lumanauw, Presiden Minta MUI Dominan Tingkatkan Kerukunan Umat Beragama, http://www. beritasatu.com/nasional/105759-presiden-minta-mui-dominan-tingkatkan-kerukunan-umat-beragama.html. diakses 25 Maret 2014 pukul 15.15 WIB.

4 Mertokusumo, Sudikno, Mengenal Hukum, Suatu Pengantar, Liberty, Yogyakarta, 2005, hlm. 77-81.

5 Ibid., hlm. 82-95. 
dan pemegang kewajiban (duty-bearer) dalam perspektif UU HAM sebagai komunikasi hukum?

Sebagai upaya untuk menjawab permasalahan di atas maka dalam studi ini akan dilakukan metode pendekatan konseptual normatif.

Hal pertama dalam penelitian ini adalah melakukan identifikasi terhadap rumusan norma dalam UU HAM yang disertai juga dengan aspek materialisasinya yang mencakup konteks legitimasi formal dan historisnya serta aspek aplikasinya dalam praktik sosial baik oleh aparatur negara maupun kegiatan masyarakat. Kerangka kerja kritik yang digunakan sebagai proses tindak lanjut dari proses identifikasi tersebut adalah kerangka kerja konsep tiga pihak (tripartite conceptual framework) dalam pandangan 'pelembagaan hukum' (Ruiter, 2001) ${ }^{6}$. Langkah akhir dari proses kritik adalah dengan melakukan kategorisasi terhadap rumusan 'pemegang hak' dan 'pemegang kewajiban' dalam UU HAM dalam posibilitas tiga kategori yaitu ideal, tidak efektif (ineffective), atau tidak legal (illegal).

\section{Pembahasan}

A. Eksistensi dan Interelasi Antara Pemegang Hak (Right Holder) dan Pemegang Kewajiban (DutyBearer) dalam UU HAM

\section{Konseptualisasi hak dan kewajiban dalam definien HAM menurut UU HAM}

Pada tahap awal untuk mengetahui eksistensi dan posisi pemegang hak dan pemegang kewajiban dalam UU HAM maka perlu dikaji terlebih dahulu tentang eksistensi hak dan kewajiban itu sendiri. Nomenklatur ' $h a k$ ' dan 'kewajiban' secara khusus tidak menjadi definiendum (kata yang didefinisikan) ${ }^{7}$ dalam UU HAM. Eksistensi keduanya secara dasar melekat pada definien HAM (definien adalah rangkaian kata pengertian yang menjelaskan definiendum) yang ada dalam Pasal 1 UU HAM, yaitu "Hak Asasi Manusia adalah seperangkat hak yang melekat pada hakikat dan keberadaan manusia sebagai mahkluk Tuhan Yang Maha Esa dan merupakan anugerah-Nya yang wajib dihormati, dijunjung tinggi dan dilindungi oleh negara, hukum, Pemerintah, dan setiap orang demi kehormatan serta perlindungan harkat dan martabat manusia." " Dari sini jelas bahwa pemaknaan 'hak'dan 'kewajiban"

6 Dick W.P. Ruiter, Legal Institutions, Kluwer Academic Publisher, Dordrecht, 2001, page 24-25. Sebagaimana disadur dalam: Anne Wagner, Wouter Werner, dan Deboran Cao, Interpretation, Law, and the Construction of Meaning, Springer, Doordrecht, 2007.

7 Bruggink, J.J. H. B. Arief Sidharta (Penerjemah), Refleksi tentang Hukum, Citra Aditya Bakti, Bandung, 1999, hlm. 72.

8 Undang-undang HAM (Undang-undang Nomor 39 Tahun 1999 tentang Hak Asasi Manusia dan UndangUndang Nomor 26 Tahun 2000 tentang Pengadilan Hak Asasi Manusia, Visimedia, Jakarta, 2007, hlm. 3-4. 
terbatasi dalam kerangka diskursus atau paradigma HAM (human rights) yang dibedakan misalkan dengan pengertian 'hak' dan 'kewajiban' dalam hukum perdata yang tertuang dalam suatu perjanjian keperdataan yang bersifat kontraktual ataupun non-kontraktual. Sebagai tambahan, untuk kata 'kewajiban'tidak tertulis secara langsung dan khusus dalam terma kata benda melainkan menggunakan kata sifat 'wajib'.

Sebagai pembanding lainnya, dalam makna yang standar atau secara leksikal, hak menurut Kamus Besar Bahasa Indonesia $(\mathrm{KBBI})^{9}$ diartikan sebagai: 1. benar (mereka telah dapat menilai mana yg hak dan mana yg batil); 2. milik; kepunyaan (barang-barang ini bukan hakmu); 3. Kewenangan (dng ijazah itu ia mempunyai hak untuk mengajar);

4. kekuasaan untuk berbuat sesuatu ( $k r n$ telah ditentukan oleh undang-undang, aturan, dsb), (semua warga negara yg telah berusia 18 tahun ke atas mempunyai hak untuk memilih dan dipilih dl pemilihan umum); 5. kekuasaan yg benar atas sesuatu atau untuk menuntut sesuatu: (menantu tidak ada hak atas harta peninggalan mertuanya); 6. derajat atau martabat: (orang Melayu pd waktu itu tidak sama haknya dng orang Eropa; 7. wewenang menurut hukum;

Identifikasi atas definien HAM di atas akan membantu untuk memunculkan karakter dari 'hak' dan 'kewajiban' dalam konteks sistem hukum HAM Indonesia. Pada ciri yang pertama dikonsepkan bahwa 'hak' itu digambarkan sebagai plural atau jamak yang diwakili oleh terma 'seperangkat'. Jadi, meskipun kata ' $h a k$ ' itu secara makna umum atau asli (ordinary meaning) diartikan sebagai bentuk tunggal tetapi dalam konteks HAM dia yang bermakna 'seperangkat', yang artinya jamak atau plural. Sebagai pembanding dan penjelas, dalam istilah bahasa Inggris hak dalam konteks HAM selalu ditulis sebagai 'human rights' dimana hak selalu ditulis dalam bentuk jamak 'rights', bukan bentuk singular 'right'.

Karakter berikutnya dari 'hak' adalah 'yang melekat'. Hal ini berarti 'hak' secara ontologis adalah sesuatu yang ada atau 'being' dan eksistensinya bersifat melekat (inherent). Inherent sendiri mempunyai makna asli sebagai "that is a basic or permanent part of $\mathrm{sb} / \mathrm{sth}$ and that cannot be removed (Oxford Advanced Learner's Dictionary, 8th edition, Oxford University Press, 2010)". Kepada entitas apakah ' $h a k$ ' tersebut dilekatkan (inherent)? Frasa berikutnya setelah 'melekat' adalah 'pada hakikat dan keberadaan manusia'. Dengan demikian, eksistensi 'hak' itu melekat (inherent) pada eksistensi 'hakikat dan keberadaan' dari 'manusia'. Menurut $\mathrm{KBBI}^{10}$, Hakikat mempunyai makna 'intisari atau dasar' atau 'kenyataan yang sebenarnya', sedangkan 'keberadaan' sendiri berarti 'ada (being)' atas diri manusia secara ontologis. 
'Hak' yang melekat dalam kedirian manusia oleh UU HAM diberikan status sebagai ‘mahkluk Tuhan Yang Maha Esa'yang posisinya sebagai 'anugerah' (entitlement), yaitu pemberian atau ganjaran atau karunia ${ }^{11}$. Dengan demikian maka posisi ' $h a k$ 'atau lebih luas lagi HAM bersifat insaniah yang profan dan bukan ajaran teologis. Hal ini perlu ditegaskan sejak awal karena HAM sendiri akan diberikan kepada seluruh manusia sebagai ciptaan Tuhan Yang Maha Esa yang justru memiliki keyakinan tentang agama atau kepercayaan yang beragam (plural). Dalam perspektif sistem nilai, bila dihubungkan antara posisi HAM dengan agama atau keyakinan, maka HAM memandang praktek teologisme seperti keberagamaan atau sejenisnya (termasuk ketidakberagamaan atau atheisme) sebagai salah satu ' $h a k$ ' atau klaim yang dimiliki oleh setiap manusia. Dengan demikian maka posisi HAM adalah memberikan pengakuan secara eksistensial (recognition) terhadap semua jenis sistem keagamaan/ kepercayaan tanpa perlu melakukan validasi atau verifikasi untuk menentukan sistem mana yang lebih baik atau lebih buruk dibanding sistem lainnya (theological judgement). Posisi HAM mempunyai makna pengakuan eksistensi teologis yang bersifat universal dan equal yang dapat menjadi dasar atau acuan bagi pengakuan terhadap semua bentuk agama atau kepercayaan. Lebih jauh lagi, HAM dalam perspektif epistemologis tidak melakukan kajian semacam perbandingan agama atau kepercayaan untuk menjadi dasar penganugerahan (entitlement) dan pengakuan (recognitian) 'hak', melainkan secara take it for granted menerima sebagai sebuah fakta objektif tentang eksistensi semua agama yang plural dalam masyarakat dan lalu menempatkannya sebagai ' $h a k$ ' untuk dihormati, dilindungi, dimajukan, dan dipenuhi.

UU HAM menjabarkan secara tandan (cluster) masing-masing hak dari 'seperangkat hak' dalam Sepuluh Bagian dari Bab III (Hak Asasi Manusia dan Kebebasan Dasar Manusia) mulai dari Pasal 9 sampai dengan Pasal 66, yaitu sebagai berikut:

1. Hak untuk hidup;

2. Hak berkeluarga dan melanjutkan keturunan;

3. Hak mengembangkan diri;

4. Hak memperoleh keadilan;

5. Hak atas kebebasan pribadi;

6. Hak atas rasa aman;

7. Hak atas kesejahteraan;

8. Hak turut serta dalam pemerintahan;

9. Hak wanita;

10. Hak anak.

Eksistensi 'hak' dalam UU HAM memberikan konsekuensi lahir dan eksisnya terma 'wajib' yang dalam kata benda menjadi 'kewajiban' (obligation atau duty). 'Wajib' sendiri secara makna asali bahasanya berarti 'harus dilakukan; tidak boleh tidak dilaksanakan (ditinggalkan)'12. 'Wajib' atau 'kewajiban' (selanjutnya disebut kewajiban) 
tersebut muncul sebagai akibat atau konsekuensi atas eksistensinya ' $h a k$ ' sehingga keduanya merupakan satu kesatuan yang tidak dapat dipisahkan. 'Kewajiban' mencakup area tindakan (obligation of action) berupa 'penghormatan', 'penjunjungtinggian', dan 'perlindungan', yang kesemuanya itu ditujukan terhadap eksistensi 'hak'. Jadi, terhadap esksitensi ' $h a k$ ', timbul sejumlah 'kewajiban' yang berupa tindakan-tindakan berupa 'menghormati', 'menjunjung tinggi', dan 'melindungi'. Secara leksikal, pertama, 'menghormati' berarti "menaruh hormat kpd; hormat (takzim, sopan) kpd: anak-anak wajib orang tua; 2 menghargai; menjunjung tinggi: kita harus $\sim$ pendapat dan keyakinan orang lain; 3 mengakui dan menaati (tt aturan, perjanjian): kita akan $\sim$ persetujuan dan perjanjian yg telah kita buat;"; kedua, 'menjunjung tingi' artinya 'memuliakan; menghargai dan menaati (nasihat, perintah, dsb); sedangkan, ketiga, 'melindungi' berarti "1 menutupi supaya tidak terlihat atau tampak, tidak kena panas, angin, atau udara dingin, dsb: anakitu $\sim$ dirinya dng daun pisang supaya tidak kehujanan; 2 menjaga; merawat; memelihara: pemerintah $\sim$ binatang yg hampir punah; 3 menyelamatkan (memberi pertolongan dsb) supaya terhindar dr mara bahaya: induk ayam itu $\sim$ anaknya thd serangan burung elang". ${ }^{13}$ Pemaknaan leksikal tersebut dilakukan karena UU HAM sendiri tidak memberikan definisi khusus terhadap terma atau definiendum

13 Ibid. 'wajib', 'menghormati', 'menjunjung tinggi', dan 'melindungi'.

Selain pemaknaan 'kewajiban' yang ada dalam definien HAM dari Pasal 1, UU HAM juga mengenalkan ketentuan yang disebut 'kewajiban dasar' yang diartikan sebagai “...seperangkat kewajiban yang apabila tidak dilaksanakan, tidak memungkinkan terlaksana dan tegaknya hak asasi manusia." Jelas disini bahwa kewajiban dasar yang berbentuk jamak tersebut, yaitu 'seperangkat kewajiban', diposisikan menjadi prasyarat untuk melaksanakan dan menegakan HAM.

Berbeda dengan pengertian 'kewajiban' dalam definien HAM yang juga menjadi komponen atau bagian dari pengertian HAM itu sendiri, 'kewajiban dasar' merupakan entitas terpisah dari HAM sebagaimana ditegaskan dalam konsideran menimbang (c) UU HAM, yaitu "bahwa selain hak asasi, manusia juga mempunyai kewajiban dasar antara manusia yang satu terhadap yang lain dan terhadap masyarakat secara keseluruhan dalam kehidupan bermasyarakat, berbangsa, dan bernegara". 'Kewajiban dasar' digambarkan sebagai seperangkat tindakan tertentu yang wajib dilakukan oleh seorang individu ketika berhubungan dengan individu yang lain, dengan publik, dan dengan negara. Penggunaan kata 'manusia' sebagai pemilik 'kewajiban dasar' mengindisikasikan aspek universalitas dari 'kewajiban dasar' tersebut, dan tidak eksklusif sebagaimana jika menggunakan kata 'warga negara'. 
Selanjutnya, bentuk dari 'kewajiban dasar' tersebut diurai dalam Pasal 67-70, Bab IV tentang 'Kewajiban Dasar Manusia', UU HAM. Dari substansi ketentuan tersebut dapat disusun sebuah daftar 'seperangkat kewajiban dasar' sebagai berikut:

1. Kewajiban setiap orang untuk patuh terhadap hukum HAM baik dalam lingkup hukum nasional maupun internasional (Pasal 67);

2. Kewajiban (bagi warga negara) untuk ikut bela negara (Pasal 68);

3. Kewajiban bagi setiap orang untuk menghormati HAM orang lain, moral, etika dan tata tertib publik (Pasal 69 ayat (1));

4. Kewajiban Pemerintah untuk menghormati, melindungi, menegakkan, dan memajukan HAM (Pasal 69 ayat (2); dan

5. Kewajiban setiap orang untuk tunduk kepada pembatasan yang ditetapkan oleh Undang-undang dengan maksud untuk menjamin pengakuan serta penghormatan atas hak dan kebebasan orang lain dan untuk memenuhi tuntutan yang adil sesuai dengan pertimbangan moral, keamanan, dan ketertiban umum dalam suatu masyarakat demokratis (Pasal 70).

\section{Konseptualisasi pemegang hak dan pemegang kewajiban dalam definien HAM menurut UU HAM}

Sampai disini dapat dimengerti bahwa menurut UU HAM, 'seperangkat hak' (rights) sebagai suatu entitas yang eksis dimiliki secara melekat oleh 'manusia' (human being), atau dapat dimengerti bahwa 'manusia' adalah entitas yang menjadi Pemegang Hak (rights holder). Terma 'manusia' dalam UU HAM tidak menjadi definiendum, atau dengan kata lain tidak mempunyai batasan-batasan tertentu atau kualifikasi kepada 'manusia' siapa saja seperangkat ' $h a k$ ' tersebut dianugerahkan. Hal ini berbeda misalkan dengan penggunaan terma 'warga negara' (citizen) yang berarti ada batas jurisdiksi kepada siapa ' $h a k$ ' diberikan dengan indikator yang lebih definitif secara hukum seperti bukti kepemilikan KTP atau Passport dan lain sejenisnya. Hal tersebut menunjukan bahwa UU HAM menganut prinsip universal terkait dengan kepada siapakah 'seperangkat hak'itu akan diberikan atau dianugerahkan oleh Tuhan Yang Maha Esa. Dengan demikian maka setiap orang yang tinggal di Indonesia menurut hukum akan masuk dalam cakupan pemegang 'hak' (rigts holder) yang wajib 'dihormati', 'dijunjung tinggi', dan 'dilindungi'. Hal ini juga sejalan dengan konsideran 'menimbang' huruf (b) UU HAM yang menyatakan "bahwa hak asasi manusia merupakan hak dasar yang secara kodrati melekat pada diri manusia, bersifat universal dan langgeng, oleh karena itu harus dilindungi, dihormati, dipertahankan, dan tidak boleh diabaikan, dikurangi, atau dirampas oleh siapapun".

Lalu siapakah yang memegang kewajiban untuk menghormati, menjunjung tinggi dan melindungi ' $h a k$ ' yang dimiliki oleh setiap 'manusia' yang berada dalam 
jurisdiksi Indonesia? Pasal 1 UU HAM menyebutkan secara eksplisit bahwa yang memegang 'kewajiban' untuk 'menghormati', 'menjunjung tinggi', dan 'melindungi' adalah: "...negara, hukum, Pemerintah, dan setiap orang...". Jadi secara hukum yang mendapat status sebagai 'pemegang kewajiban' (duty-bearers) adalah 'Negara', 'Hukum', 'Pemerintah', dan 'Setiap orang'. Dengan demikian maka terhadap setiap hak yang dimiliki oleh 'setiap orang' di Indonesia secara hukum akan dihormati, dijunjungtinggi, dan dilindungi oleh Negara, Hukum, Pemerintah, dan 'setiap orang'. UU HAM tidak mendefinisikan secara khusus tentang makna dari terma 'Negara', 'Hukum', 'Pemerintah', dan 'Setiap orang'. Selain itu, untuk 'kewajiban dasar', yang mempunyai pemegang kewajiban yaitu 'setiap orang', 'warga negara', dan 'pemerintah'.

\section{Diagram 1. Konseptualisasi HAM}

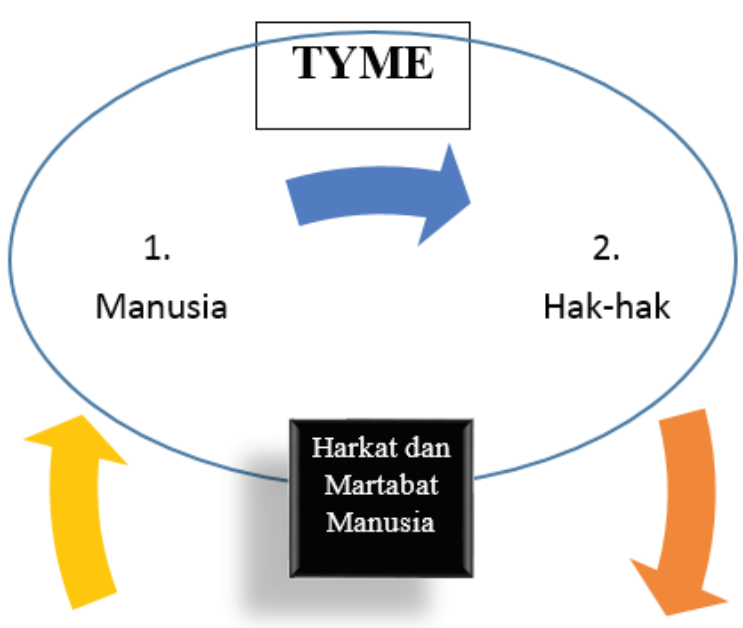

4.

Duty-bearers

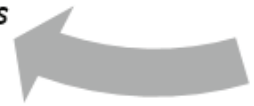

Kewajiban
Sampai disini, apabila disederhanakan dalam bentuk diagram, maka konseptualisasi 'hak', 'kewajiban', 'pemegang hak', dan 'pemegang kewajiban' dalam definien HAM menurut UU HAM adalah sebagai berikut:

Pada pusat diagram terdapat 'harkat dan martabat manusia' sebagai inti tujuan mengapa HAM itu harus ada. 'Harkat dan martabat manusia' diupayakan melalui penganugerahan 'hak-hak' atau 'seperangkat hak' kepada setiap 'manusia' yang bersifat universal. Penganugerahan hak yang bersifat universal kepada seluruh umat manusia tersebut langsung berasal dari 'Tuhan Yang Maha Esa'. Keberadaan 'hak-hak' yang melekat pada eksistensi 'manusia' tersebut membawa konsekuensi lahirnya 'kewajiban' kepada pihak-pihak tertentu atau 'duty-bearers', yaitu 'Negara', 'Hukum', 
'Pemerintah', dan 'setiap orang', agar 'hakhak' tersebut dihormati, dijunjungtinggi, dan dilindungi. Dalam siklus itulah maka ' $h a k$ hak' dapat menjadi sejumlah klaim yang dimiliki oleh individu atau kelompok individu untuk diajukan kepada pemegang kewajiban.

Diagram tersebut tidak memasukan 'kewajiban dasar' karena dia berada di luar definien HAM dan di sisi lain 'kewajiban dasar' tersebut diposisikan sebagai entitas yang menjadi prasyarat agar HAM (yang termasuk di dalamnya komponen ' $h a k$ ' dan 'kewajiban') dapat dilaksanakan dan ditegakan. Jadi, 'kewajiban dasar' mempunyai penekanan pada aspek perealisasian dari ' $h a k$ ' dan 'kewajiban', dan bukan untuk menjelaskan tentang eksistensi HAM itu sendiri, termasuk komponen-komponenya.

\section{B. Konstruksi Kritik atas Perumusan Pemegang Hak (Rights Holder) dan Pemegang Kewajiban (Duty- Bearer) dalam UU HAM}

\section{Membingkai konseptualisasi norma pemegang hak (rights holder) dan pemegang kewajiban (duty-bearer) dalam UU HAM menurut kerangka kerja konsep tiga pihak (tripartite conceptual framework)}

Sebagai salah satu produk hukum yang berisi standar perilaku atau norma bagi masyarakat dan otoritas negara, UU HAM terbangun dan terekspos dalam struktur teks bahasa. Penggunaan teks bahasa tidak lepas dari eksistensi asali dari hukum yang selalu melekat pada eksistensi masyarakat sebagai pengguna bahasa, ius societas ubi ius, di mana ada masyarakat di situ terdapathukum. Artinya, substansi hukum agar dipahami sehingga berlaku secara efektif dalam mempengaruhi perilaku sosial maka kandungan norma yang terangkai dalam teks (kata dan kalimat) harus dapat dikomunikasikan oleh para pihak, khususnya antara otoritas negara dengan setiap anggota masyarakat. Komunikasi antara teks hukum dalam UU HAM dengan para stakeholderdes (otoritas negara dan anggota masyarakat) bertujuan agar perilaku sosial masyarakat dan tindakan negara seiring dan sejalan dengan pemajuan, pemenuhan, perlindungan, dan penghormatan HAM demi harkat dan martabat manusia. Dengan demikian maka UU HAM secara formal adalah instrumen berbentuk simbol bahasa (fenomena bahasa hukum) di satu sisi dan fenomena praktek sosial (social practices) pada sisi objek sasaran intervensinya.

Interelasi antara hukum sebagai fenomena linguistik yang supersensible (tidak terperi dalam dunia fisik) ${ }^{14}$ dengan aspek praktik sosial akan membentuk kerangka kerja konsep tiga pihak (tripartite conceptual framework) sebagai berikut:

14 Olivecrona, Karl, Las as Fact Stevens and Sons, London, 1971, page 223 sebagaimana dikutip dalam Anne Wagner, Wouter Werner, dan Deboran Cao, Interpretation, Law, and the Construction of Meaning, Springer, Doordrecht, 2007. 
1. Hukum sebagai bentuk aturan formal yang sah dan diterima (legitimate) dan berisi pesan-pesan (dimensi material) ${ }^{15}$;

2. Tindakan aplikasi aturan formal oleh pejabat berwenang (official) atau oleh hakim melalui putusannya menyangkut suatu perkara di pengadilan;

3. Suatu tingkatan tertentu dari pola penyelarasan perilaku terhadap aturan (rule-conforming pattern of behaviour) dalam praktik sosial ${ }^{16}$.

Pada sub-sistem pertama, aturan hukum yang formal, sah dan diterima, seperti ketentuan UU HAM menyangkut pemegang hak dan pemegang kewajiban, merupakan suatu konstruksi yang tidak dapat terlihat secara jelas dan mudah dimengerti (indiscernible) $^{17}$ dan berbentuk pemikiran atau ide gagasan yang menjadi dasar bagi subsistem kedua dan ketiga. Setiap rangkaian kata atau teks dalam aturan hukum berisi suatu proyeksi dari gambaran atau citra tertentu yang ditujukan untuk menjadi realitas dalam dunia nyata. Pesan substantif yang ada dalam hukum mempunyai konstruksi mental, bukan fisik, yang menjadi objek pemikiran ideal, sehingga untuk mencari realitas imajinernya seseorang harus melakukan suatu pemikiran. Hal ini berbeda misalnya ketika suatu rangkaian kata atau teks mempunyai pesan substantif yang mengacu pada objek fisik, semisal kursi, rumah, atau mobil, maka seseorang dengan relatif mudah untuk mencari realitas imajinernya.

Berbeda dengan sub-sistem pertama, subsistem kedua dan ketiga dapat terlihat secara jelas dan mudah dipahami (discernible). Tindakan para pejabat berwenang dalam mengaplikasikan suatu aturan atau ketika hakim menggunakan hukum dalam menangani suatu perkara di pengadilan relatif mudah dipersepsikan. Demikian juga pola perilaku individu dan masyarakat dalam praktek-praktek sosial yang terkait dengan penyesuaian aturan termasuk mudah untuk diamati (observable).

Dari kerangka kerja tiga pihak atau subsistem tersebut, tercermin adanya relasi resiprokal antara aturan hukum sebagai sebuah fenomena bahasa atau linguistik dengan fenomena hukum sebagai bagian dari praktik-praktik sosial. Hukum yang sah dan diterima (legitimate) sudah pasti mempunyai konstruksi sebagai rangkaian ungkapan katakata (utterance) yang mempunyai potensi kekuatan untuk mengatur perilaku sosial masyarakat. Akan tetapi, tidak serta merta suatu aturan hukum mempunyai dampak terhadap praktik sosial sampai saatnya dia diaplikasikan melalui tindakan hukum pejabat publik, digunakan sebagai konsideran dalam putusan atau penetapan hakim, atau menjadi

15 Materiil atau material disini berarti menjadikan suatu ide atau nilai yang abstrak menjadi norma hukum yang lebih nampak dan eksis.

16 Dick W.P. Ruiter, Legal Institutions (Dordrecht: Kluwer Academic Publisher, 2001), page 24-25. Anne Wagner, Wouter Werner, dan Deboran Cao, Interpretation, Law, and the Construction of Meaning, Springer, Doordrecht, 2007.

17 Ibid., hlm. 25. 
acuan bagi pola perilaku sosial masyarakat. Terhadap situasi ini, secara kategoritatif maka akan terdapat tiga kemungkinan, yaitu:

1. Ideal, artinya gambaran atau citra yang dihasilkan oleh hukum secara keseluruhan adalah bentuk materialisasi yang sebangun dengan pola perilaku sosial;

2. Tidak efektif (ineffective), artinya realitas imajiner sebagai gambaran atau citra yang dihasilkan oleh aturan hukum, meskipun aturan hukumnya sah dan diterima (legitimate), tetapi bukan bagian dari keyakinan bersama yang melandasi praktik hukum.

3. Ilegal (illegal), artinya terdapat suatu realitas imajiner sebagai bagian dari keyakinan bersama yang melandasi praktik hukum, tetapi bukan merupakan hasil proyeksi dari suatu aturan hukum yang sah dan diterima (legitimate) ${ }^{18}$.

Terhadap eksistensi UU HAM khususnya terkait norma pemegang hak (rights holder) dan pemegang kewajiban (duty-bearer) dapat dianalisis secara kritis (kritisisme) dengan menggunakan kerangka analisa tripartite conceptual framework tersebut. Tujuan utama dari kritisisme tersebut adalah untuk mengukur derajat lejitimasi legal formal dari UU HAM khususnya terkait pemaknaan HAM, lalu sejauh mana fisibilitas norma tersebut untuk diaplikasikan baik oleh aparatur negara maupun melalui perilaku masyarakat.
Selanjutnya, hasil penilaian akan bermuara pada penentuan posisi alternatif di antara tiga kategori, apakah konstruksi idenya termasuk ideal, tidak efektif, atau ilegal.

\section{Mengukur derajat legitimasi atas materialisasi norma pemegang hak dan pemegang kewajiban dalam UU HAM}

UU HAM secara historis lahir sebagai salah satu penanda penting bagi datangnya era reformasi yang berkehendak menempatkan hak asasi manusia sebagai bagian terpenting dari sistem hukum Indonesia. Setelah disahkan pada 23 September 1999 dan dicantumkan dalam Lembar Negara Republik Indonesia Nomor 165 maka UU HAM mempunyai kekuatan mengikat secara hukum terhadap setiap otoritas negara dan anggota masyarakat. Sekitar satu tahun sebelumnya, tepatnya 13 November 1998, penguatan isu HAM sudah dimulai melalui pengesahan Ketetapan MPR No.XVII/MPR/1998 tentang HAM (selanjutnya disebut TAP Piagam HAM) yang di dalamnya memperkenalkan istilah Piagam HAM. TAP Piagam HAM tersebut lalu menjadi salah satu konsideran 'mengingat' dalam UU HAM meskipun kemudian pada tahun 2003 dicabut melalui ketentuan Pasal 1 Ketetapan MPR/1/MPR/2003 tentang Peninjauan terhadap Materi dan Status Hukum Ketetapan MPRS dan Ketetapan MPR-RI Tahun 1960 sampai dengan Tahun

18 Hanneke Van Schooten dalam Bab Law as Fact, Las as Fiction: A Tripartite Model of Legal Communication, Wagner et al (eds.), Interpretation, Law and the Construction of Meaning, Dordrecht, Netherland, 2007, hlm. 3-20. 
2002. Teks HAM lalu muncul secara eksplisit dalam konstitusi Indonesia yang secara nomenklatur menjadi judul dari Bab XA, dan karenanya menjadi hak dasar, sebagai hasil Perubahan Kedua terhadap Undang-Undang Dasar Negara Republik Indonesia Tahun 1945 (selanjutnya disebut UUD NRI Tahun 1945) pada tahun 2000 .

Teks ' $h a k$ ' sebelum muncul dalam UU HAM dan TAP Piagam HAM ternyata telah diintrodusir dalam Pembukaan (Preambule) Konstitusi Indonesia Alinea Ke-1 yang menyatakan "Bahwa sesungguhnya kemerdekaan itu ialah hak segala bangsa...". Kemudian, sebagaimana dikutip dalam konsideran 'mengingat' UU HAM, batang tubuh UUD NRI Tahun 1945 pra-amandemen telah juga mengatur beberapa ' $h a k$ 'yang pada saat itu meliputi: hak atas persamaan dalam hukum dan pemerintahan (Pasal 27 ayat (1)); hak atas pekerjaan dan penghidupan yang layak (Pasal 27 ayat (2)); jaminan hukum terhadap kemerdekaan berserikat, berkumpul, mengeluarkan pikiran baik secara lisan maupun tertulis (Pasal 28); jaminan terhadap hak beragama dan beribadah (Pasal 29 ayat (2)); kewajiban negara terhadap pemajuan kebudayaan (Pasal 32); jaminan alokasi penguasaan negara atas kekeyaan sumberdaya alam untuk kesejahteraan publik (Pasal 33 ayat (3)); dan jaminan pemeliharaan oleh negara terhadap masyarakat miskin dan terlantar (Pasal 34).

Konsideran 'menimbang' UU HAM pada poin (a), (b), (c), dan (d) memberikan referensi pada aspek non-yuridis dalam proses materialisasi konsep normatif HAM termasuk elemen pemegang hak dan pemegang kewajiban. Substansi dari konsideran tersebut secara singkat meliputi:

a. HAM adalah anugerah dari Tuhan untuk menjamin harkat dan martabat manusia;

b. HAM bersifat melekat pada eksistensi manusia, langgeng, dan universal yang harus dilindungi, dihormati, dipertahankan dan tidak boleh diabaikan, dikurangi, atau dirampas oleh siapapun;

c. Manusia selain memiliki HAM juga mempunyai kewajiban dasar manusia;

d. Indonesia mempunyai tanggung jawab moral dan hukum sebagai anggota PBB untuk menjunjung tinggi dan melaksanakan Deklarasi Universal Hak Asasi Manusia (Universal Declaration of Human Rights) beserta instrumen HAM internasional lainnya yang telah diteirma oleh Indonesia.

Demikian juga secara historis konstitusional Indonesia, ternyata UndangUndang Dasar Sementara Republik Indonesia (UU No. 7 Tahun 1950, LN 1950-56, d.u. 15 Ag 1950) pada saat itu juga telah memuat ketentuan normatif tentang ' $h a k$ ' yang masuk dalam Bagian 5 tentang Hak-hak Dan Kebebasan-kebebasan Dasar Manusia. Hal ini menunjukan bahwa sudah sejak awal era kemerdekaan isu tentang HAM telah menjadi perhatian penting bagi para pendiri negara. Dan hal tersebut juga dapat menjadi indikator bahwa mereka para perumus pada saat itu 
telah berinteraksi dengan aktivisme hak asasi manusia pada level dunia internasional saat era pasca kolonialisasi dan perang dunia kedua.

Selain mempunyai rujukan sejarah, hukum, sosial, dan filosofis, semenjak disahkan UU HAM belum pernah secara formal menjadi objek suatu uji konstitusionalitas (judiciil review) ke Mahkamah Konstitusi. Kritik yang ditujukan terhadap UU HAM masih dibawah tingkat kehendak untuk mengubahnya baik secara sebagian maupun keseluruhan sehingga secara praktis dan yuridis masih valid dan diterima (legitimate). Bahkan setelah amandemen konstitusi kedua pada tahun 2000, ketentuan ' $h a k$ ' baik secara substansi maupun formal semakin kuat karena munculnya Bab XA tentang Hak Asasi Manusia yang dalam pasal-pasalnya mengatur lebih detail dan lengkap tentang 'seperangkat hak'.

'Seperangkat hak' yang diakui dalam bentuk cluster oleh UU HAM secara substantif mencakup semua hak-hak dasar yang diatur dalam Bab XA UUD NRI Tahun 1945, dari Pasal 28A - 28J. Proses materialisasi secara substantif hak-hak dasar tersebut apabila dilihat secara garis waktu (timeline) justru semuanya diadopsi dari ketentuan yang ada dalam UU HAM yang setahun lebih awal dibentuk daripada amandemen kedua konstitusi pada tahun 2000. Namun secara hirarkhi sudah pasti kemudian 'seperangkat hak dan kewajiban' dalam konstitusi menjadi lebih tinggi derajat normanya terhadap 'seperangkat hak dan kewajiban' yang ada dalam UU HAM.
C. Prospek aplikasi otoritatif oleh lembaga negara dan adaptasi oleh praktik sosial atas konstruksi normatif pemegang hak (rights holder) dan pemegang kewajiban (duty-bearer) dalam UU HAM

Konstruksi normatif pemegang hak dan pemegangkewajibanbersifatindiscernible (tak mudah digambarkan sebagai realitas imajiner) yang membutuhkan peran otoritas negara yang relevan agar dapat terwujud sebagai sesuatu yang lebih riil (discernible). Pejabat eksekutif dan yudikatif merupakan pihak yang paling relevan untuk mengaplikasikan konsep gagasan normatif tersebut dalam suatu peristiwa hukum yang nyata. Pada sisi yang lain, muatan dari konsep norma pemegang hak dan pemegang kewajiban tersebut juga akan bisa diidentifikasi secara lebih melalui pola perilaku masyarakat dalam merespon dan menerjemahkannya dalam praktik-praktik kehidupan sosial.

Konstruksi definien HAM menurut Pasal 1 UU HAM menempatkan pemegang hak dan pemegang kewajiban sebagai bagian dari sebuah kesatuan sistem. Makna HAM yang tergambar dari Diagram 1. Pemegang hak (rights holder) dalam siklus di atas adalah manusia secara universal sebagai makhluk Tuhan dengan tanpa adanya suatu batasan tertentu seperti kewarganegaraan, status sosial, jenis kelamin, paham politik, warna kulit, ras, suku, agama dan lain sebagainya. Terjadi transformasi penggunaan terma 'manusia' yang bersifat universal 
menjadi frasa 'Setiap orang...' dalam UU HAM. Hal tersebut mengacu pada batasan jurisdiksi sistem hukum Indonesia sebagai tempat dibentuk dan berlakunya UU HAM. Dengan demikian, terma 'manusia' sebagai pemegang hak yang bersifat universal lebih kuat aspek moralitasnya dibandingkan dengan penggunaan teks 'setiap orang' yang kuat sekali nuansa teknis yuridisnya. Keduanya tidak bertentangan namun lebih kepada konsekuensi legalisasi HAM dalam sebuah konteks sistem hukum yang bersifat domestik.

Dalam kerangka kerja konsep tiga pihak (tripartite conceptual framework), konkritisasi pemegang hak berada dalam subsistem kedua (aplikasi otoritatif oleh pemerintah atau hakim) dan subsistem ketiga (pola penyelarasan perilaku terhadap aturan dalam praktik sosial). Pemerintah merupakan pejabat administrasi yang bertugas menjalankan kebijakan-kebijakan umum pemerintahan berdasarkan arahan undang-undang dengan menggunakan instrumen yuridis berupa kebijakan umum administratif dan keputusankeputusan administratif yang konkrit. Sedangkan hakim bertugas menerapkan dan menemukan hukum terhadap suatu kasus di pengadilan, termasuk yang bersifat penetapan. Objek dari keputusan administratif pejabat pemerintah dan putusan atau penetapan hakim di pengadilan selalu kompatibel dengan proses aplikasi konsep normatif pemegang hak, yaitu 'manusia' atau 'setiap orang' sebagai subjek hukum (naturlijkpersoon). Sedangkan terkait pola perilaku penyelarasan terhadap aturan dalam praktik sosial, 'manusia' atau 'setiap orang' sebagai subjek hukum dapat berupa tindakan pengajuan klaim kepada 'pemegang kewajiban' untuk menghormati, menjunjung tinggi, memenuhi, dan melindungi.

Konsep normatif terma 'manusia/setiap orang' sebagai pemegang hak dalam UU HAM mempunyai hasil proyeksi hukum yang fisibel untuk diaplikasikan dalam tindakan administratif aparatur pemerintah maupun oleh hakim melalui suatu putusan atau penetapan pengadilan. Demikian juga ketika terma tersebut dituangkan dalam bentuk aktivitas klaim melalui tindakan konkrit oleh masyarakat. Dengan demikian sangat relevan untuk menempatkan aspek eksistensial komponen pemegang hak yaitu 'manusia atau setiap orang' dalam kategori ideal. Ideal dalam artian gambaran yang dihasilkan dari proyeksi materialisasi 'pemegang hak' yaitu 'manusia atau setiap orang' kompatible atau bersesuaian dengan sistem (hukum) perilaku sosial dari tindakan administratif aparatur pemerintah, mekanisme pembuatan putusan atau penetapan oleh hakim di pengadilan, dan pola perilaku penyesuaian aturan oleh masyarakat.

Terhadap status 'manusia' atau 'setiap orang' sebagai pemegang hak, HAM menempatkannya sebagai situasi alami tanpa suatu predikat kekuasaan dalam suatu struktur negara. Artinya, 'manusia' atau 'setiap orang' itu secara spesifik adalah warga negara atau penduduk yang mendiami yurisdiksi sistem hukum Indonesia. Sedangkan ketika seseorang 
sudah menjadi bagian dari kekuasaan negara karena pilihan pekerjaan yang dengannya dia dianugerahi seperangkat kewenangan atau kekuasaan yang bersifat publik, maka secara hukum dia sudah bukan lagi bagian dari 'manusia' atau 'setiap orang' yang dilekati status sebagai pemegang hak. Pelekatan ' $h a k$ ' kepada aparatur negara akan tetap ada atau eksis sebagai sebuah potensi yang tidak hilang, dan akan muncul lagi ketika dalam situasi 'bebas', 'lepas' atau tidak lagi menyandang status sebagai pihak berwenang dalam kehidupan publik. Sejauh kewenangan publik itu masih melekat pada diri seorang pejabat negara dalam kurun tempat dan waktu tertentu sesuai dengan karakter Tupoksi jabatan (tugas pokok dan fungsi), maka akan menegasikan statusnya sebagai pemegang 'hak'. Jenis ' $h a k$ ' yang hilang juga mesti satu karakter atau relevan dengan jenis 'kewenangan' yang melekat, contoh, seorang polisi akan kehilangan hak atas keamanan saat sedang menjaga demonstrasi, seorang guru atau dosen akan hilang hak untuk mendapatkan pengajaran ketika sedang bertugas di sekolah atau kampus, hak untuk hidup seorang tentara akan hilang ketika dia sedang bertempur, hak untuk banding dalam sistem peradilan yang terbuka akan hilang dari seorang hakim ketika dia sedang memerika kasus di pengadilan, dan lain sebagainya. Sayang sekali, hal ini tidak dijelaskan secara otoritatif (dalam bagian penjelasan) oleh UU HAM sehingga masih sering terungkap kerancuan tentang pemahaman siapa yang harus dilekati status sebagai pemegang hak dan bagaimana cara mengaplikasikan kata 'setiap orang' dalam praktik-praktik sosial maupun pelaksanaan kewenangan negara.

Dari analisis sebelumnya dapat disimpulkan bahwa status sebagai pemegang suatu hak tertentu itu sifatnya hanya eksis dan dimiliki oleh 'orang' atau 'manusia' jika dan hanya jika yang bersangkutan bukan atau tidak sedang menjalankan fungsi kewenangan atau kekuasaan publik atas hak tertentu itu. Konsep ini terkait dengan aspek fisibilitas atau dapat dijalankannya ' $h a k$ ', karena HAM bukanlah suatu konsep utopis atau filosofis semata, tapi juga lahir dan menjadi bagian dari praktik kehidupan keseharian manusia. Dari sini, lalu siapakah yang berposisi sebagai 'yang memenuhi hak' tersebut?

Sebagaimana digambarkan dalam diagram tentang makna HAM di atas, pelekatan 'seperangkat hak' pada 'manusia' atau 'setiap orang' membawa konsekuensi tuntutan terhadap eksisnya sebuah entitas yang disebut 'pemegang kewajiban'. UU HAM menentukan bahwa pemegang kewajiban (duty-bearer) terdiri dari: Negara, Hukum, Pemerintah, dan Setiap-orang. Secara sederhananya, semua entitas yang terkait aktivitas masyarakat dan tata kelola kekuasaan negara yang ada di Indonesia mempunyai status sebagai 'pemegang kewajiban', sebab di Indonesia sudah tidak ada lagi entitas di luar 'negara, hukum, pemerintah, dan setiap-orang'. Makna dari 'negara' sendiri sudah mencakup elemen Pemerintah, Rakyat atau setiap-orang, 
serta hukum itu sendiri sebagai dasar adanya eksistensi negara, semisal konstitusi. Secara pelembagaan dan pengembanan kekuasaan, negara juga mencakup eksekutif, legislatif, dan yudikatif beserta lembaga-lembaga kuasi-nya. Dalam beberapa literatur HAM, kata Negara (State) biasanya dipersempit maknanya menjadi entitas pemegang kekuasaan yang kedudukannya dilawankan dengan warga negara sebagai pihak yang tidak mempunyai otoritas atau kewenangan untuk mengatur kehidupan publik. Cakupan kelembagaan negara juga dibuat sedemikian fleksibel menyangkut organ apa saja dan bagaimana kualifikasinya untuk dapat dianggap sebagai bagian dari kekuasaan negara. Kata negara dalam konteks diskursus HAM tentu tidak mencakup rakyat atau penduduk sebagaimana diskursus tentang asal-usul berdirinya negara beserta elemen-elemennya dalam ilmu negara.

Memaknai 'kewajiban' sebagai beban yang harus diselenggarakan oleh para 'pemegang kewajiban' terhadap setiap klaim yang dilakukan oleh para 'pemegang hak', maka bagaimanakah terkait mekanisme pelaksanannya jika semua entitas kemudian menjadi pemegang kewajiban? Oleh siapa dan kepada siapa kewajiban tersebut akan dilaksanatujukan? 'Seperangkat hak' merupakan sekian klaim yang menyangkut kehidupannyatadariparapemegangnya, seperti salah satunya adalah hak atas pendidikan yang secara aplikasinya membutuhkan anggaran yang besar, pelembagaan kementerian yang kompleks, penyusunan kurikulum, dan lain sebagainya. Memang benar bahwa negara, pemerintah, hukum, dan setiap orang harus menyadari akan eksistensi ' $h a k$ ' dan masingmasing mempunyai peran dan kontribusi. Tapi jika tidak ada suatu peran yang jelas di antara para pemegang kewajiban, artinya pembebanan kewajiban tersebut menjadi sulit untuk ditindaklanjuti dalam tataran yang lebih konkrit seperti dalam bentuk kebijakan pemerintah, keputusan administratif, maupun putusan atau penetapan pengadilan.

Pembebanan 'seperangkat kewajiban' kepada negara, pemerintah, dan hukum adalah hal yang masih relevan karena semua elemen itu adalah bagian dari kekuasaan negara. Kekuasaan negara mempunyai daya paksa yang legal untuk mewujudkan pemajuan, perlindungan, dan pemenuhan 'seperangkat hak'. Negara dilengkapi dengan instrumen hukum sebagai legitimasi untuk melaksanakan program-programnya yang mungkin dilekati dengan paksaan dan sanksi di dalamnya atas nama kepentingan bersama atau publik. Beban kewajiban yang ditanggung oleh negara adalah bentuk konsekuensi atas diserahkannya sebagian kedaulatan pribadi warga negara yang dimanifestasikan dalam bentuk kewenangan-kewenangan yang berbasis rule of law. Nampak disini bahwa hukum bukanlah berfungsi sebagai subjek pelaksana dari suatu 'kewajiban', melainkan law as an instrument of an end, hukum sebatas menjadi alat dari suatu tujuan yaitu memberikan beban kewajiban HAM kepada para pemangkunya. Karena 'hukum' bukan merupakan suatu 
subjek hukum (rechtpersoon) yang dapat melakukan suatu perbuatan hukum maka menjadi terasa janggal jika kemudian oleh UU HAM diberi status sebagai pemangku kewajiban.

Entitas terakhir yang menjadi pemegang kewajiban dalam konsep normatif UU HAM adalah 'setiap orang'. Terma 'setiap orang' tidak menjadi definiendum dalam UU HAM dan dianggap sebagai kata umum yang setiap orang tahu artinya. Setiap-orang dapat mengacu pada setiap individu yang ada dalam jurisdiksi UU HAM, yaitu seluruh teritori Indonesia, baik statusnya sebagai warga negara maupun penduduk. 'Setiap orang' sebagai pemegang kewajiban dalam kerangka definien HAM berarti setiap-orang yang bukan bagian dari pemangku kekuasaan negara, pemerintah maupun hukum. Dengan demikian, 'setiap orang' disini merupakan entitas yang sama dengan 'setiap orang' yang statusnya sebagai 'pemegang hak' sebagaimana yang telah diterangkan sebelumnya.

Pertanyaan mendasar atas status ganda bagi 'setiap orang' sebagai pemegang hak sekaligus pemegang kewajiban adalah tentang fisibilitasnya, daya keterlaksanaannya. Karakter eksistensial ' $h a k$ ' di satu sisi adalah sebagai dasar pengajuan suatu klaim, sedangkan karakter eksistensial 'kewajiban' di sisi yang lain adalah sebagai yang mengabulkan klaim tersebut. Lalu, bagaimana kedua hal yang harusnya dilaksanakan oleh dua entitas berbeda kemudian dijalankan oleh entitas yang tunggal? Konstruksi relasional tersebut terasa sulit untuk dapat dipahami secara jelas. Memang, dalam konsep 'setiap orang' mengandung arti dan menuntut bahwa setiap individu yang satu perlu menyadari (awareness) akan eksisnya 'seperangkat hak' yang dimiliki oleh individu yang lain. Tetapi awareness tersebut bukan merupakan bagian, dan perlu dibedakan, dari 'seperangkat kewajiban'. 'Seperangkat hak' eksis dan melekat pada keberadaan manusia karena semata-mata anugerah dari Tuhan, dan bukan sebagai hadiah kepada manusia karena telah melakukan 'seperangkat kewajiban' tertentu. Contoh paling mudah adalah tentang 'seperangkat hak' yang dimiliki oleh seorang anak semata-mata statusnya sebagai manusia dan bukan diberikan karena anak tersebut telah menyelesaikan 'seperangkat kewajiban tertentu'. Demikian juga dengan hak hidup yang diberikan kepada setiap orang bukan karena manusia pada awalnya telah melakukan 'seperangkat kewajiban' tertentu, melainkan bentuk kemurahan dari Tuhan Yang Maha Esa.

Terkadang terdapat fakta bahwa jika seseorang ingin menjalankan, mendapatkan, atau menikmati ' $h a k$ '-nya, maka dia sebagai 'pemegang hak' bersama dengan otoritas publik sebagai 'pemegang kewajiban' harus melakukan suatu tindakan tertentu secara resiprokal seperti melakukan pembayaran, pendaftaran, mengikuti kegiatan tertentu dan lain sebagainya. Semisal, jika seseorang ingin mendapatkan hak untuk bekerja maka dia harus melakukan suatu pendidikan atau 
pelatihan tertentu yang mana di dalamnya bisa juga menuntut prasyarat berupa pembayaran iuran pendidikan dan lain sejenisnya. Hal seperti melakukan pembayaran dan pendidikan tersebut yang dilakukan oleh 'pemegang hak' bukanlah bagian dari pelaksanaan 'seperangkat kewajiban', melainkan pemenuhan dari 'syarat penyelenggaraan' suatu 'hak'. Pelaksanaan atau pemenuhan 'Syarat penyelenggaraan' bisa dilakukan secara bersamaan atau sharing antara pemegang hak dengan pemegang kewajiban. Korelasi 'syarat penyelenggaraan' dengan eksistensi hak adalah bahwa 'syarat penyelenggaraan' akan menentukan sejauh mana kualitas atau kuantitas ' $h a k$ ' dapat dihormati, dilindungi dan dipenuhi. 'Syarat penyelenggaraan' tidak mempunyai korelasi causa prima dengan eksistensi 'seperangkat hak'. Berhasil atau gagalnya, terpenuhi atau tidaknya suatu 'syarat penyelenggaraan' tidak mempengaruhi eksistensi suatu ' $h a k$ ' yang telah melekat pada diri seorang 'pemegang hak'. Seorang wali murid yang tidak mampu membayar biaya pendidikan bagi sekolah anaknya tidak kemudian menghilangkan eksistensi hak atas pendidikan yang dimiliki oleh anaknya, melainkan akan mengganggu atau mengurangi kadar kualitas penyelenggaraan pendidikan yang akan dinikmati oleh sang anak. Dengan tetap eksisnya hak atas pendidikan yang dimiliki oleh anak tersebut maka proses klaim haknya terhadap pemegang kewajiban masih dapat dilakukan seperti melakukan tuntutan ke dinas pendidikan, hearing ke DPRD, mengajukan gugatan ke pengadilan dan lain sebagainya. Dan sebaliknya, aspek kekurangan sumber daya dalam proses penyelenggaraan ' $h a k$ 'tidak kemudian menghapus beban 'kewajiban'yang dimiliki oleh para pemangku 'seperangkat kewajiban'. Tingkat ketersediaan sumber daya tidak berkorelasi terhadap aspek eksistensialnya 'kewajiban', namun hanya berpengaruh pada tingkat kualitas atau kuantitas hasil pelaksanaan 'kewajiban'.

Dari penjelasan sebelumnya dapat dirumuskan pendapat bahwa materialisasi 'pemegang kewajiban' mengandung contradictio in terminis khusunya menyangkut status dari 'setiap orang' sebagai 'pemegang kewajiban' yang sekaligus juga menjadi 'pemegang hak'. Konsekuensi dari materialisasi tersebut adalah terjadinya kekaburan proyeksi gambaran imajiner yang dihasilkan oleh UU HAM sehingga tidak sesuai dengan atau sulit diterapkan dalam praktik sosial yang dilakukan oleh pemangku kewenangan negara ataupun individu dalam masyarakat. Fakta ini menyebabkan materialisasi 'pemegang kewajiban' berkontribusi terhadap ketidakefektifan (ineffectiveness) penegakan UU HAM sebagai pedoman dalam perilaku sosial di lingkup pemerintahan, peradilan, dan kehidupan sosial masyarakat.

Pada sisi yang lain, Pasal 8 UU HAM mentransformasikan beban 'kewajiban' menjadi lingkup 'tanggung jawab' sembari menegaskan bahwa diantara 'pemegang 
kewajiban' maka Pemerintah menempati posisi utama sebagai pemegang 'tanggung jawab'. Lebih jelasnya, ketentuan Pasal 8 UU HAM tersebut menyatakan bahwa "Perlindungan, pemajuan, penegakan, dan pemenuhan hak asasi manusia terutama menjadi tanggung jawab Pemerintah". Jadi dengan pasal tersebut proses transformasi pemaknaan definien HAM terkait 'kewajiban' dan 'pemegang kewajiban' diawali dari pengubahan nomenklatur 'kewajiban' menjadi 'tanggung jawab' yang diikuti dengan penempatan pemerintah sebagai 'pemegang tanggung jawab' yang utama.

Namun demikian, Bab V UU HAM membedakan antara kewajiban dan tanggung jawab tanpa merinci lebih jauh faktor-faktor apa saja yang menjadi pembedanya. Judul dari Bab V adalah "Kewajiban dan Tanggung Jawab Pemerintah" yang meliputi Pasal 71 dan Pasal 72 dengan isi ketentuan:

\section{Pasal 71}

"Pemerintah wajib dan bertanggung jawab menghormati, melindungi, menegakan, dan memajukan hak asasi manusia yang diatur dalam Undang-undang ini, peraturan perundang-undangan lain, dan hukum internasional tentang hak asasi manusia yang.diterima oleh negara Republik Indonesia”.

\section{Pasal 72}

"Kewajiban dan tanggung jawab pemerintah sebagaimana dimaksud dalam pasal 71, meliputi langkah implementasi yang efektif dalam bidang hukum, politik, ekonomi, sosial, budaya, pertahanan keamanan negara, dan bidang lain".

Kata penghubung 'dan' menunjukan bahwa kedua terma tersebut adalah entitas yang berbeda. Namun demikian, substansi 'kewajiban' dan 'tanggung jawab' dalam Pasal 71 dan 72 tidak berbeda sama sekali alias sebangun sehingga timbul pertanyaan mengapa digunakan terma yang berbeda jika substansinya sama.

Lebih lanjut, amandemen kedua Konstitusi pada tahun 2000 juga menegaskan proses transformasi tersebut melalui Pasal 281 ayat (4) yang menyatakan bahwa "Perlindungan, pemajuan, penegakan, dan pemenuhan hak asasi manusia adalah tanggung jawab negara, terutama pemerintah". Jika dibandingkan dengan UU HAM, ketentuan konstitusi tersebut lebih jelas dan tidak mengandung contradictio in terminis karena menempatkan pemangku kekuasaan negara, khususnya pemerintah, sebagai entitas tunggal pemegang 'tanggung jawab'. Yang menjadi persamaan adalah keduanya berbagi dalam penggunaan terma 'tanggung jawab' yang menggantikan kata 'kewajiban'.

Secara leksikal, 'tanggung jawab' mempunyai arti sebagai: 1 keadaan wajib menanggung segala sesuatunya (kalau terjadi apa-apa boleh dituntut, dipersalahkan, diperkarakan, dsb): pemogokan itu menjadi -- pemimpin serikat buruh; 2 Hukum fungsi menerima pembebanan, sbg akibat sikap 
pihak sendiri atau pihak lain. ${ }^{19}$ Sedangkan 'kewajiban' mempunyai arti: 1 (sesuatu) yg diwajibkan; sesuatu yg harus dilaksanakan; keharusan: tugas penelitian sudah merupakan $\sim$ bagi setiap calon sarjana; 2 pekerjaan; tugas: aku akan melaksanakan tugas $\sim k u$ dng saksama; 3 Huk tugas menurut hukum; manusia segala sesuatu yg menjadi tugas manusia (membina kemanusiaan); moral kewajiban atas dasar norma benar dan salah sebagaimana diterima dan diakui oleh masyarakat; sosial kewajiban atas dasar norma dan tingkah laku lingkungan sosial. ${ }^{20}$ 'Tanggung jawab' pada aspek pelaksanaannya lebih banyak menekankan kepada kesadaran internal sehingga terhadap ketidakterlaksanaannya maka si pemegang tanggung jawab mendapat status telah melakukan sebuah kelalaian. Penegakan tanggung jawab lebih bersumber dari dorongan moral, etika serta kesadaran diri, dan bukan karena paksaan ketentuan suatu aturan hukum. Pada sisi lain, 'kewajiban' lahir karena si 'pemegang kewajiban' sebelum mendapatkan beban kewajiban terlebih dahulu pada dirinya dilekati suatu kewenangan yang bersifat publik oleh hukum. Jadi, kewajiban lahir sebagai konsekuensi atas kewenangan yang telah diberikan sebelumnya oleh hukum. Ketika si 'pemegang kewajiban' tidak menjalankan apa yang telah dibebankan kepadanya maka dia dikatakan telah melakukan sebuah 'pelanggaran'.
Contoh praktek penggunaan tanggung jawab dan kewajiban adalah terkait pemenuhan hak anak. Perlindungan, pemenuhan, pemajuan, dan penghormatan hak anak adalah menjadi beban kewajiban negara khususnya pemerintah sehingga kalau tidak terpenuhi maka dikatakan negara khususnya pemerintah telah melakukan suatu pelanggaran terhadap hak anak. Sedangkan orang tua dan masyarakat dikatakan sebagai pemegang tanggung jawab untuk memelihara, menjaga, dan memenuhi hak-hak anak. Tanpa adanya tanggung jawab tersebut maka pemenuhan hak-hak anak tidak dapat terselenggara secara optimal, efektif dan berkemajuan. ${ }^{21}$ Jadi, dalam konteks relasional 'pemegang hak' dan 'pemegang kewajiban', penggunaan tanggung jawab dan kewajiban tidak dapat dipersamakan meskipun dalam konteks linguistik secara umum terdapat persamaan elemen diantara keduanya.

\section{Simpulan}

Berdasarkan analisis yang telah dilakuan dengan mengacu pada rumusan masalah serta hasil temuannya, maka dalam penelitian ini dapat dirumuskan kesimpulan sebagai berikut: a. Materialisasi konsep norma pemegang hak dan pemegang kewajiban dalam UU HAM mengandung contradictio in terminis khususnya terkait dengan kedudukan 'setiap orang' dalam definien HAM. Di satu sisi 'setiap orang' adalah pemegang hak yang 
denganya dapat melakukan sejumlah klaim kepada pemegang kewajiban yaitu para pemangku kewenangan negara. Akan tetapi pada saat yang sama 'setiap orang' juga dilekati status sebagai pemegang kewajiban yang karena sifat eksistensialnya justru akan menegasikan seperangkat hak yang secara pre-eksis sudah dimilikinya. Selain itu, UU HAM tidak memberikan ketentuan yang jelas tentang cakupan dari kewajiban yang dibebankan kepada 'setiap orang' untuk dibedakan dari yang dibebankan kepada para pemangku kewenangan negara. Padahal antara entitas 'setiap orang' dengan entitas pemangku kewenangan negara mempunyai karakter eksistensial yang sangatberbeda. 'Setiap orang'adalah manusia biasa yang telah menransfer sebagian kedaulatan individunya kepada entitas aparatur negara melalui instrumen rule of law demi mencapai tujuan bersama. Dengan demikian, kewenangan hukum merupakan dasar dari lahirnya beban kewajiban sehingga tidak mungkin untuk dimiliki oleh 'setiap orang' yang memang secara asali merupakan manusia biasa (penduduk atau warga negara) yang merupakan entitas pemegang hak.

b. Secara formal ketentuan pemegang hak dan pemegang kewajiban dalam UU HAM mempunyai tingkat keabsahan dan keterterimaan (legitimacy) yang cukup kuat sehingga dikategorikan sebagai ideal. Hal ini menjadi refleksi betapa kuat dan dinamisnya kebutuhan akan diskursus HAM sehingga pada level tertentu masih bisa menolelir dan menerima kekaburan makna yang ada dalam definien HAM menurut UU HAM. Aktivisme di bidang HAM yang cukup tinggi di Indonesia memberikan mekanisme substitusi kekurangjelasan materialisme konsep normatif deniniens HAM semisal melalui perujukan konten norma yang ada dalam sekian banyaknya perjanjian HAM internasional yang telah diratifkasi Indonesia.

Meskipun ideal di tingkat legal formal; tetapi pada tingkat aplikasi administratif oleh aparatur pemerintah, aplikasi ajudikatif oleh hakim dalam putusan atau penetapan di pengadilan, maupun aplikasi dalam pola perilaku penyesuaian aturan dalam praktek kehidupan sosial oleh setiap orang; materialisasi definien HAM berpotensi sekali untuk mengalami inefektifitas dalam aplikasinya. Kategori inefektifitas ini diakibatkan oleh kekaburan realitas imajiner yang diproyeksikan oleh definien HAM sehingga berpotensi munculnya tumpang tindih (overlap), kekaburan makna (vague norm) , kerancuan sehingga mempersulit dan mereduksi derajat efektifitas pada tingkat perilaku sosial dalam pemerintahan, pengadilan, dan masyarakat.

a. Pada tataran ideal, para legislator jika mempunyai momen untuk melakukan perubahan terhadap UU HAM maka harus menghapus kedudukan 'setiap 
orang' sebagai pemegang kewajiban dan sebaliknya lebih menekankan peran pemegang kewenangan negara sebagai pemegang kewajiban dengan konstruksi teks yang lebih lugas, jelas dan tidak tumpang tindih. Peran 'setiap orang' sebagai pemegang hak adalah ikut berpartisipasi dalam proses penyelenggaraan dan dapat dibebani tanggung jawab tertentu secara relevan tanpa perlu menransformasika kedudukannya sebagai pemegang hak menjadi pemegang kewajiban.

b. Terhadap potensi inefektifitas aplikasi UU HAM karena contradictio in terminis dalam definien HAM; pada wilayah pemerintahan maupun pengadilan dapat menggunakan ketentuan-ketentuan yang ada dalam perjanjian internasional HAM yang telah diratifikasi Indonesia beserta prinsip-prinsipnya sebagai pedoman dalam membuat putusan dan tindakan administratif. Penafsiran hukum (legal interpretation) dapat menjadi instrumen penting bagi para aparatur penegak hukum khususnya hakim dalam proses penemuan hukum (rechtsvinding) yang diakibatkan oleh kekaburan norma yang dihasilkan dari proses materialisasi elemen HAM dalam UU HAM.

\section{DAFTAR PUSTAKA}

\section{Buku}

Anne Wagner, Wouter Werner, dan Deboran Cao, 2007, Interpretation, Law, and the Construction of Meaning, Springer, Doordrecht.

Austin Sarat dan Thomas R. Keams (Eds), 1995, Law's Violence, The University of Michigan Press, Michigan.

Bruggink, J.J. H. B. Arief Sidharta (Penerjemah), 1999, Refleksi tentang

Hukum, Citra Aditya Bakti, Bandung.

Denise Meyerson, 2006, Essential

Jurisprudence, Routledge Cavendish,

New South Wales.

Guyora Binder dan Robert Weisberg, 2000, Literary Criticisms of Law,

Princenton University Press, Princeton.
Ian Ward, 1998, An Introduction to Critical

Legal Theory, Cavendish Publishing Limited, London \& Sydney.

James W. Nickel, 2007, Making Sense of Human Rights. Second Edition, Blackwell Publishing, Massachusetts.

John Bowring, 2013, The Works of Jeremy Bentham, 1843, Volume II. Edinburgh (William Tait). 18381843. Direproduksi secara e-book oleh Liberty Fund Inc., Indianapolis, USA.

KBBI Offline 1.5.

Michel Rosenfeld, 1998, Just Interpretation: Law between Ethics and Politics, University of California Press, Berkeley, Los Angeles, London. 
Peter Mahmud Marzuki, 2008, Penelitian Hukum Online, Komnas HAM Temukan

Hukum, Kencana, Jakarta.

Sudikno Mertokusumo, 2005, Mengenal

Hukum, Suatu Pengantar, Liberty, Yogyakarta.

Tom Campbell, 2004, Prescriptive Legal

Positivism: Law, Rights and

Democracy, Cavendish Publishing Limited, New South Wales.

William Twining, 2009, General

Jurisprudence: Understanding Law

from a Global Perspective, Cambridge

University Press, Cambridge.

\section{Jurnal}

Cecile Fabre, 2000, The Dignity of Rights,

Oxford Journal of Legal Studies,

Volume 20, No.2, Oxford.

\section{Naskah Internet}

BBC Indonesia, Kasus Cebongan, tidak melanggar HAM, http:// www.bbc.co.uk/indonesia/berita_ indonesia/2013/04/130411_menhan_ kasus_cebongan.shtml.
Pelanggaran HAM Kasus Cebongan, http://www.hukumonline.com/berita/ baca/1t51c18e3b23ff9/komnas-hamtemukan-pelanggaran-ham-kasuscebongan.

Novy Lumanauw, Presiden Minta MUI Dominan Tingkatkan Kerukunan Umat Beragama, http://www. beritasatu.com/nasional/105759presiden-minta-mui-dominantingkatkan-kerukunan-umat-beragama. html.

Unicef, Kewajiban dan Tanggung Jawab, http://www.unicef.org/indonesia/ id/03_kewajiban_tanggung_jawab.pdf.

\section{Peraturan Perundang-undangan}

Undang-Undang Dasar Negara Republik Indonesia Tahun 1945.

Undang-Undang Dasar Sementera 1950.

Undang-undang Nomor 39 Tahun 1999 tentang Hak Asasi Manusia. 